\title{
Practices and Countermeasures of Cross-border Insolvency Under Chinese Law
}

\author{
Wang Deling, Wu Changyue ", Wang Yubao, Li Junfeng \\ Merchant Marine College, Shanghai Maritime University, Shanghai, China \\ Email address: \\ dlwang@shmtu.edu.cn(Wang Deling), cywu@shmtu.edu.cn (Wu Changyue),wangyb@njcit.cn (Wang Yubao), \\ Jeffersonlijf@hotmail.com (Li Junfeng) \\ ${ }^{*}$ Corresponding author
}

\section{To cite this article:}

Wang Deling, Wu Changyue, Wang Yubao, Li Junfeng. Practices and Countermeasures of Cross-border Insolvency Under Chinese Law. International Journal of Business and Economics Research. Vol. 8, No. 6, 2019, pp. 382-388. doi: 10.11648/j.ijber.20190806.18

Received: October 10, 2019; Accepted: November 5, 2019; Published: November 15, 2019

\begin{abstract}
As the globalization of economy accelerates greatly, more and more cross-border trade and investment is inevitably coming into being, resulting in many bankruptcy cases in which the relationship of creditor's rights and debts is no longer limited to the territory of a country. In recent years, the most influential case is the bankruptcy case of Hanjin Shipping. Hanjin Shipping's bankruptcy has had a great impact on the international shipping market, the global supply chain has been interrupted, and a large number of commercial disputes have been triggered. The problems of insolvency international cooperation and the conflicts between bankruptcy and ship arrest proceedings in cross-border insolvency case have aroused widespread concern of experts and scholars in shipping. China has not adopted "UNCITRAL Model Law on Cross-border Insolvency", making the case more complicated to deal with the proceedings under jurisdiction of China. In order to deal with cross-border bankruptcy cases in China and better protect the interests of stakeholders, this paper makes a detailed analysis of the legal provisions on cross-border bankruptcy under Chinese law, and statistically analyzes the practice of Chinese courts in dealing with cross-border bankruptcy cases. Through a comparative analysis of the similarities and differences of legal provisions and practices between China and "UNCITRAL Model Law on Cross-border Insolvency" and other typical countries, this paper puts forward some suggestions and countermeasures to deal with similar cross-border bankruptcy cases under the jurisdiction of Chinese courts in the future.
\end{abstract}

Keywords: Cross-boarder Insolvency, Model Law, Admiralty Lien, Recognition and Enforcement, Belt and Road Initiative

\section{Introduction}

On August 31, 2016, Hanjin Shipping Co., Ltd.(Hanjin hereafter), the world's top 10 shipping giant, filed bankruptcy protection to the Central District Court in Seoul, South Korea, and on September 1, the court judged the acceptance of its application. On September 2, Hanjin initiated bankruptcy reorganization proceedings. Hanjin held its first creditors' meeting on November 11 of that year. It was originally scheduled to submit the reorganization plan on December 23, but the submission was significantly delayed because of the complexity of the case. On February 17, 2017, the Central District Court in Seoul, South Korea declared, in view of the fact that the liquidation value of Hanjin Shipping exceeded the going value, Hanjin Shipping was officially bankrupt. Thus the bankruptcy case of the largest shipping company in the history of the global shipping industry became a reality.
Since the official announcement of Hanjin Shipping bankruptcy, it has had a great impact on the international shipping market, the global supply chain has been interrupted, and a large number of commercial disputes have been triggered. Because the case affected dozens of shipping countries, each country gave different ways of bankruptcy protection and the degree of protection, especially when the bankruptcy protection measures conflict with the ship arrest system, the attitudes of the courts in different countries are different, so the problems of insolvency international cooperation, and the conflicts between bankruptcy procedure and ship arrest procedure in cross-border insolvency case have aroused widespread concern of experts and scholars in shipping. Creditors have applied to the courts of various countries for ship arrest and other property preservation, and then initiated the proceedings. As to cases that has come to courts under Chinese jurisdiction, according to incomplete 
statistics, the Shanghai Maritime Court has accepted 16 cases, with a total of more than RMB 200 million involved; the Ningbo Maritime Court has accepted 11 cases, with a total of more than RMB 800 million involved; and the Xiamen Maritime Court has accepted 11 cases, etc.

As the globalization of the world economy accelerated greatly in the $1980 \mathrm{~s}$, under the background of cross-border trade and investment, the cross-border actions inevitably lead to the cross-border of property relations, resulting in many bankruptcy cases in which the relationship of creditor's rights and debts is no longer limited to the territory of a country. Such bankruptcy is called "cross-border insolvency" for its foreign element. [1] In order to solve the complex legal problems of cross-border insolvency, United Nations Commission on International Trade Law adopted "the Model Law on Cross-border Insolvency" at its 30th session in May 1997. The UNCITRAL Model Law on Cross-border Insolvency ("the Model Law" hereafter), although not yet widely adopted, but has been enacted in several major economies ${ }^{1}$, Some other countries, although not enact the Model Law, have adopted the same frame, e.g. Singapore. [2]. Notwithstanding the fact that the Model Law implies the development and trend on international cooperation, China, as one of the major economics and shipping countries, has not enacted the Model Law, and not make any operational mechanism in line with the same. This situation makes practice of cooperation complicated on cross-border insolvency under the jurisdiction of China. In the case that a maritime matter is involved in insolvency proceedings in China, situation becomes more complicated, as there is no legal instruments by which conflicts between proceedings of admiralty and insolvency can be reconciled ${ }^{2}$. [3]

When a shipowner becomes insolvent or it can not avoid such situation especially as the shipping market is down, it may petition for bankruptcy protection, by which its assets can be precluded from being seized by creditors. [4] Whereas when assets are located in foreign jurisdictions, especially when a ship in its ownership or chartered by it is trading overseas, the case will be worsen off. As we know, the admiralty proceeding would give priority to protecting creditors' interests against the shipowner's assets, in contrast, the principle of insolvent law prefer to allow all of debtor's assets to be distributed to the creditors under a single standard, notwithstanding creditors are domiciled in foreign countries or in the debtor's domestic jurisdiction. [5] Conflicts arise when the aforesaid two procedures encounter with each other, and more confusions occur when different jurisdictions make different choices of priority between maritime and bankruptcy procedures. This paper makes a discussion with respect to practice of international cooperation of cross-border insolvency in China, and new development of international cooperation in the field of cross-boarder insolvency is

1 Some of the enacting countries are either main shipping counties including Australia, Canada, Japan, Korea, South Africa, the U.K., and the United States etc. 2 Controversies can not be calmed as both Maritime Code and Enterprise Bankruptcy Law are enacted by the same legislature, regulating specific matters in different field. introduced, based on which foreign companies may seek the possibility to protect their assets or satisfy their claims. Furthermore, several main conflicts between proceedings of admiralty and insolvency under the circumstance of Chinese jurisdiction are probed into based on the analysis of legislation and practices. Principles of the Model Law will be also referred to so as to analyse the differences between other major shipping countries and China.

\section{Legislation and Practice of Cross-border Insolvency in China}

\subsection{Legal Environment}

The only provision on cross-border insolvency in Chinese law is Article 5 of "Enterprise Bankruptcy Law of the People's Republic of China ${ }^{3}$ ("the Bankruptcy Law" hereafter), which adopts the concept of "absolute universal-ism" in the case that proceedings initiated in the territory of China according to this law. As for proceedings applying for recognition or enforcement triggered by a foreign court, the Chinese court to whom the application is made will examine whether any international treaties are concluded or conceded between China and the country where the judgement or ruling are made. Furthermore, this law accommodate the principle of reciprocal under the circumstance that no treaties exist. [6]

Although that the Bankruptcy Law does not stipulate foreign debtor and creditor' legal status, whether the debtor are given the right to petition for bankruptcy protection for their assets located in China, and whether creditors stand a chance of distributing assets equally with domestic creditors where the same are under bankruptcy proceeding in particular, the Civil Procedure Law of PRC, another law which regulating the bankruptcy procedure, grants the same litigation rights and protections to foreign debtors and creditors as the citizens, legal persons, or other organizations of the People's Republic of China ${ }^{4}$, i.e. foreign creditors can participate in insolvency proceedings initiated in the territory of China, on the other hand, enterprises established in China by foreigners can file petition for bankruptcy protection before a competent domestic court pursuant to the Bankruptcy Law.

\footnotetext{
3 Article 5 of the Bankrutcy Law provides that Once the procedure for bankruptcy are initiated according to this Law, it shall come into effect in respect of the debtor's property outside of the territory of the People's Republic of China. Where a legally effective judgment or ruling made on a bankruptcy case by a court of another country involves a debtor's property within the territory of the People's Republic of China and the said court applies with or requests the people's court to recognize and enforce it, the people's court shall, according to the relevant international treaties that China has concluded or acceded to or on the basis of the principle of reciprocity, conduct examination thereof and, when believing that the said judgment or ruling does not violate the basic principles of the laws of the People's Republic of China, does not jeopardize the sovereignty and security of the State or public interests, does not undermine the legitimate rights and interests of the creditors within the territory of the People's Republic of China, decide to recognize and enforce the judgement or ruling.

4 Article 5 of The Civil Procedure Law of PRC.
} 


\subsection{Confusions Arising from the Legislation with Respect to Cross-border Insolvency Issues}

The Bankruptcy Law of China stipulates cross-border insolvency in an over-synoptical way, rather than a concrete one, and it adopts the principle of "reciprocity", which is not in line with the trend of practice of modern insolvency cooperation. That gives rise to confusions in practice. [7]

As discussed in section 2.1, the law adopts the principal of absolute universal-ism in the condition that an insolvency proceeding is opened within the territory of China. But there has been no further any operational system in the form of law to facilitate the international cooperation of cross-border insolvency. The key issue in this aspect is whether the orders on insolvency procedures granted by Chinese court can be recognized by a foreign court. It is normal understanding that there is a higher possibility of recognition of judgement and/or ruling made by countries when a treaty is concluded. [8] More than 30 bilateral treaties on mutual legal assistance in civil and commercial matters have been concluded, but China has not enacted any multilateral treaties, such as the Model Law. Among these bilateral treaties, some of them stipulated mutual recognition and enforcement of judgment and ruling, such as treaties concluded with France, Italy, Spain, Bulgaria, Hungary, etc., whereas some of them, although governing assistance in civil and commercial matters, do not include any provisions with respect to mutual recognition and enforcement of judgement and ruling made by courts of both countries ${ }^{5}$, such as treaties with Thailand, Singapore, South Korea etc.. [9] In addition to these countries who have entered into a treaty with China, recognition and insolvency protection made by courts of some other counties which have not concluded any treaties in this field, especially some main trading countries, will be decided by their local law. In the case of "Zhejiang Jianshan Photoelectric co., Ltd", Intermediate People's Court Haining Zhejiang ("Haining Court "hereafter) initiated reorganization (rehabilitation) proceeding ${ }^{6}$ upon the application of the Debtor, "Zhejiang Jianshan Photoelectric co., Ltd" ("the debtor" hereafter) in December 2013. When the reorganization proceeding was in progress, assets in an amount of 1.5 billion RMB were located in the territory of USA. The administrator designated by Haining Court, as the foreign representative ${ }^{7}$ of the debtor, approach to US Bankruptcy Court of New Jersey ("the foreign court" hereafter) and pursued for insolvency protection and relief. The foreign court recognized the reorganization proceeding

5

http://www.fmprc.gov.cn/web/ziliao_674904/tytj_674911/wgdwdjdsfhzty_67491 7/t1215630.shtml.

6 Case No. 1-5 [2014] Judgement of HaiNing Intermediate Court.

7 Forgeign representative is one of the important definitions prescribed in (d) 2 Article of the Model law, and U.S adopted the definition by (24) Article 101 of U.S. Bankruptcy Code. It is one of the most important difference that there is no concept of "foreign representative" under the bankruptcy law of P. R. C. the administrator, in this case, was designated pursuant to Chapter 3 of the bankruptcy law. It filed the application, and managed to certify itself as the foreign representative pusuant to U.S. Bankruptcy Code in the application. as the Foreign Main Proceeding under Chapter 15 of the U.S. Bankruptcy Code (the enactment of the UNCITRAL Model Law), an interim relief order was decided by the foreign court prescribed that all creditors were precluded from any form of execution against the debtors assets. This is a successful case in which a bankruptcy reorganization ruled by a Chinese court has been recognized by the United States, but not all cases have the same effect.

The principle of reciprocity adopted by courts of PRC was once construed in the manner of "de facto reciprocity"in an early stage. The supreme court of China replied to Dalian intermediate court in the case on"the Application of Gomi Akira (A Japanese Citizen) to Chinese Court for Recognition and Enforcement of Japanese Judicial Decision" that "there are neither international treaties concluded or acceded to between China and Japan on the recognition and enforcement of judgments and written orders made by each others' courts, nor any corresponding relationship of reciprocity established". Therefore, Dalian intermediate Court made a final written order on November 5, 1994, in which the applicant's request was rejected. Seven years after the case, Osaka high court Japan refused to recognize and execute ruling delivered by Shangdong High Court, China in consideration of the case of Gomi Akira. Another example, in 2001, in the application for recognition and enforcement of the bankruptcy judgment of a Italian court heard by the Foshan Intermediate People's Court of Guangdong Province, China, the court recognized the legal effect of the bankruptcy judgment made by the Italian court on the basis of "the Treaty between the People's Republic of China and the Republic of Italian on Civil Mutual legal Assistance". It can be seen that Chinese courts has been gradually accepted limited universal-ism in dealing with the recognition of foreign bankruptcy proceedings in China.

The principle of reciprocity as accommodated by the Bankruptcy Law are criticized by experts and scholars. Firstly, the principle of reciprocity is international reprisals by its very nature. In the case that a foreign debtor seeking recognition or reliefs, the debtor's position will be impaired by action of the court in his own country. Specifically, decision of rejecting to recognize the foreign proceeding is made by the local court, rather than the debtor, but the debtor should burden the adverse consequence. It is more unfair in the situation that the debtor may not even be of the same nationality as the rejecting court.[10] Secondly, the principle of reciprocity may never have a chance to occur, especially under the circumstance that both countries insist "de facto reciprocity" ${ }^{\prime \prime}$, as non of them are willing to step forward first to break the deadlock.

\subsection{Development of the Principle of Reciprocity Under the "Belt and Road Initiative" in China}

With the development and growth of economy, more and

8 The concept of "de facto reciprocity" emphasizes that a court should not recognize a foreign judgement or ruling unless recognitions in the same nature have been made by one court in that foreign country. 
more foreign companies open their business in China and domestic enterprises, set up their branches or subsidiaries overseas. International cooperation of cross-border insolvency is demanded by the present economic situation. The most significant reform relating to the interpretation to article 5 of the Bankruptcy Law of China is indicated in "The Supreme Court' Declaration with respect to Providing Legal Service and Safeguard for the Belt and Road Initiative" ("the Declaration" hereafter) promulgated in July 2015, in which "presumed reciprocity" is adopted in article 6 of the declaration. Despite the declaration has removed the "de facto reciprocity", it will still take a long period to implement the new interpretation in practice, taking into account that the declaration is made for the countries which support the Belt and Road Initiative. And the Belt and Road Initiative is a initiative only, rather than a concrete international body or organization, therefore, it is difficult to identify clearly which countries are giving positive response to the Initiative. Moreover, the declaration, although promulgated by the supreme court, is not a formal source of law under the jurisdiction of Chinese court ${ }^{9}$.

Furthermore, a joint statement was issued at the 2nd China-ASEAN Justice Forum on $8^{\text {th }}$ June 2017 in Nanning, the capital of the Guangxi Zhuang Autonomous Region, called "Nanning Statement", by which the concept of "presumed reciprocity" was reiterated. It states that, among the forum attending countries which do not concluded any treaties with respect to mutual legal assistance in civil and commercial matters, the reciprocal relationship should be presumed to exist on condition that no judicial precedents indicating any application for recognition or enforcement had been rejected by the corresponding foreign courts. Although the Statement is not in the form of treaties, and courts are not clearly bounded by it, it still implied the developing tendency that the concept of "presumed reciprocity" are more appropriate and acceptable than "de facto reciprocity" in China. The "presumed reciprocity" has been built up in the Nanning Statement. In the previous judicial practice, the unspecified standards of reciprocity and the insistence on factual reciprocity caused the other countries' retaliation to China. With the promotion of the Belt and Road initiative, the application of reciprocity needs to combine the notion of comity, and applying comity as a precondition of reciprocity. It will promote China to have a positive stance in the free movement of global judgments on civil and commercial matters. It is predictable that the "presumed reciprocity" will be widely accepted in the near future and international cooperation of cross-boarder insolvency proceeding will benefit from the tendency.

\footnotetext{
9 The widely accepted formal source of law is the laws and regulations based on which a judgement or rulling can be made under Chinese law includes laws, promulgated by the National People's Congress and its standing commitee, administrative regulations, Local regulations, administrative rules, etc., although judicial interpretations of the Supreme People's Court, the declaration in this paper, are taken into consideration when a judgment or ruling is made, they can not be ranked as one source of law.
}

\section{Conflicts Between Admiralty Proceedings and Cross-border Bankruptcy Proceedings}

One of the most troublesome aspects of the relationship between cross-border insolvency and admiralty proceedings ${ }^{10}$ is the fact that different countries give different priorities to insolvency proceedings. [11] The Model Law deliberately leave this question to the countries who have enacted $\mathrm{it}^{11}$. Therefore, even countries in the same treaty are still entitled to make different choices. In the Model Law article 20 (2), it stipulates that a the Model Law enacting country can provide that the Article 20 (1) stay does not apply to a pre-existing action by any secured claimant, including one who has proceeded to seize a ship by arrest or attachment. [12] For instance, Hanjin commenced its bankruptcy proceeding at Seoul Central District Court on 31 August 2016, soon afterwards, it took legal actions in jurisdictions worldwide to prevent its vessels and other assets from being seized or avoid being seized. One US Bankruptcy Court recognized the proceeding commenced in South Korea as the main foreign proceeding ${ }^{12}$, and granted full protection for assets located in America, including that pre-existing secured claims should be stayed. In contrast, jurisdictions such as in Singapore, Canada, allowed the continuation of secured claims, notwithstanding the subsequent bankruptcy recognition was filed.

\subsection{Comparison of Admiralty and Cross-border Bankruptcy Proceedings Under Chinese Law}

There is no detailed provisions with respect to the conflicts between the bankruptcy proceeding and secured claims, especially claims made by arrest of the debtor's ship. Proceeding of ship's arrest and auction are provided in chapter 3 of Maritime Procedure Law of The People' Republic of China. Whereas article 19 of the Bankruptcy Law stipulated that all preservation measures taken against the debtor's property shall be lifted and enforcement procedures shall be stayed, once the court accepts the bankruptcy petition. It seems the adoption of principle of "lex specialis derogat generalis" can not address the issue for the reason that both of them govern different specific subject matter. The prevailing view in practice is that ship arrest is a normal mechanism of preserving procedure for civil litigation in its nature under Chinese legal circumstance, rather than action in rem as

10 In accordance to maritime procedure law of P. R. C., the scope of maritime proceeding should include arrest and auction of ships, attachment and auction of cargo, maritime injunction, maritime security, procedure for constitution of limitation fund for maritime claims, procedure for registration and satisfaction of claims etc., this paper mainly discuss the ship's arrest proceeding.

11 The Model Law 20 (2) states that "the scope, and the modification or termination of the stay and suspension referred to in paragraph 1 of this article are subject to [refer to any provisions of law of the enacting state relating to insolvency that apply to exceptions, limitations, modifications or termination in respect of the stay and suspension referred to in paragraph 1 of the article]".

12 In accordance to the Model Law, article 2 (b), "Foreign main proceeding" means a foreign proceedings taking place in the state where the debtor has the center of its main interests. 
adopted in common law ${ }^{13}$. It is, therefore, that the arrest of creditor's ship should be lifted pursuant to article 19 of bankruptcy law. It seems that positions of ship arrest and insolvency are clear when both apply to Chinese laws. In the case of "Xin Dong Fu", Ningbo Maritime court approved the application of arrest of MV "Xin Dong Fu" on May13, 2013 and auction on $20^{\text {th }}$ of the same month subsequently. However, Ningbo Maritime court was advised that the district court, LeQing people's court had approved the owner's petition for insolvency proceeding. Ningbo Maritime Court stayed the auction of MV "XIN DONG FU", and entrusted the vessel to the administrator of the owner's assets ${ }^{14}$.

At first sight, the issue as discussed above is internal conflicts within the jurisdiction of Chinese law, rather than the issue of international cooperation of insolvency proceedings. But foreign creditors should be aware the differences on this issue between China and other countries when they attempt to satisfy their secured claim by arrest of the debtor's ships or any other assets located in China. Some main shipping jurisdictions, such as Singapore, Canada, Australia, the United Kingdom ${ }^{15}$, etc., allow the continuation of secured claims prior to the commencement of a insolvency proceeding, especially in the form of admiralty lien in shipping field, while it may be just opposite in China.

\subsection{Priority of Claims Secured by Admiralty Lien Among Secured Claims in the Proceeding of Distribution of the Debtor's Asset}

Another main issue is priority of claims secured by admiralty lien among secured claims in the proceeding of distribution of the debtor's asset. It seems beyond doubt that admiralty lien claims should be regarded as secured claims in common law system, but conflicts arise under the jurisdiction of China due to that the position of the admiralty lien is not stipulated in the bankruptcy law. [13] This issue is critical in international cooperation. On one hand, position of the admiralty lien is critical for a foreign court to decide whether to recognize the proceeding commenced in China courts. On the other hand, it is the main consideration by foreign creditors to decide whether to participate in the insolvency proceeding opened by one Chinese

13 This view of point is elaborated by Judge Wu Shengshun of Ningbo Maritime Court in his recent article "conflicts and reconciliation between admiralty proceedings and insolvency proceedings", see http://www.nbhsfy.cn/info.jsp?aid=27130, visited on 3rd October 2019.

14 Case No. Execution 63-67 [2013] Judgement of Ningbo Maritime Court Wenzhou detached tribunal, Entrusted Execution 6 [2013] Judgement of Ningbo Maritime Court Wenzhou detached tribunal, Insolvency 13 [2013] Judgement of Wenzhou Leqing peopel's Court.

15 Martin Davies explored the extents in details in "Cross-border insolvency and admiralty - a middle path of reciprocity", Extent of protection given by the listed countries are not always the same, for example, the United Kingdom provides that the admiralty claimant can continue to proceed against the proceedings of a judicial sale notwithstanding that the opening of insolvency proceeding, but if the admiralty proceedings have not reached the point of judicial sale when insolvency proceedings are opened, the claimant cannot continue the maritime proceeding but must participate in the insolvency proceedings, Australia and Canada provide that a insolvency proceeding in the stage of rehabilitation may stay the maritime proceeding, but if the insolvency proceeding has reached to the stage of liquidation, the maritime proceeding cannot be stayed. court, or to proceed to other jurisdiction to arrest the debtor's ships or attach its other assets. [14]

Five types of claims are granted with admiralty lien by the Maritime Code of Peoples' Republic of China ("the Maritime Code" hereafter), namely (a) claims for wages, other remuneration, repatriation etc., (b) claims for loss of life or injury. (c) claims for ship's port charges including tonnage dues, pilot dues etc. (d) claims for salvage. (e) claims for loss or damage resulting from tortious act. All the above claims are ranked over the claims secured by possessory lien or ship mortgage. In accordance to the Bankruptcy Law, in respect to the distribution proceeding against the debtor's assets, creditor's claims secured by possessory lien and ship mortgage are allowed to be satisfied prior to distribution the debtor's assets, then the distribution should in the following orders: (a) wages and other payments prescribed by relevant labor laws and administrative regulations; (b) the social insurance premiums and the taxes; (c) ordinary claims.

Some experts support that all the five types of claims secured by admiralty lien should be ranked over possessory lien and ship mortgage in the distribution of a debtor's assets ${ }^{16}$, while some are of the opinion that admiralty lien is not necessary to be taken into consideration after the insolvency proceeding has been commenced, as type (a), (b), (c) of admiralty lien have been categorized as claims over ordinary claims by their nature, pursuant to the the article 113 of the Bankruptcy Law, type (d) and (e) should be treated as ordinary claims. This paper is of the same view with the former, as the concept of admiralty lien is wildly accepted and taken into consideration by most of shipping countries when a insolvency proceeding is started. On one hand, disregard of the admiralty lien in a insolvency proceeding may undermine development of cooperation on cross-border insolvency. On the other hand, admiralty lien is one of the cornerstone of maritime law, and ignorance of its existence may give rise to great confusion, not only in insolvency, but also in shipping and insurance industry. [15]

\section{Suggested Measures to Deal with Cross-border Insolvency Under Chinese Law}

\subsection{Sue in a Chinese Court}

In fact, Chinese creditors took the lead in filing proceedings in Chinese courts, and the Chinese judiciary ruled for the first time in cases involving Hanjin bankruptcy. As of April 12, 2019, according to incomplete statistics, 71 bankruptcy cases against Han Jinhai have been disposed of by Chinese courts.

16 The same view of point is presented by Judge Wu Shengshun of Ningbo Maritime Court in his recent article "conflicts and reconciliation between admiralty proceedings and insolvency proceedings", see http://www.nbhsfy.cn/info.jsp?aid=27130, visited on 4th October 2019. In this case, the applicant's own country's attitude towards to "the Belt and Road Initiative initiative" should be either examined, as the declaration as mentioned above is made mainly for the purpose of providing convenience for "the Belt and Road Initiative". 
Specifically, there were 38 cases in which Han Jin Shipping was the defendant. The Chinese court accepted the request of domestic creditors to seize Hanjin owned ships in China territory and preserve other property of Hanjin Shipping, but 10 of the 38 cases were terminated because Korean Shipping had no property to execute in China. Therefore, proceedings should not be instituted if it is found that a bankrupt company has no property enforceable in China, as the effect of enforcement by a Chinese court decision is limited to the territory of China. If a lawsuit in a Chinese court fails to make up for the loss, creditors may consider going to the country where the bankrupt protection was filed as soon as possible to participate in the bankruptcy liquidation.

\subsection{Consider the Possibility of Recognition of Foreign Proceedings}

China has not adopted the Model Law. It can be concluded that possibility of recognition for foreign proceeding may vary depending on conditions such as treaties, judicial precedents and state's policies. In particular, a foreign debtor who intent to pursue insolvency protection under the territory of PRC should examine the following:

1. A treaty with respect to mutual recognition and enforcement of judgment and ruling should be concluded between China and the debtor's own country, or otherwise.

2. A judicial precedents, in which judgment or ruling made by courts of china was recognized by the applicant's own country' courts. At least no case in which judgment of ruling were rejected to recognize, If neither treaties, nor judicial precedents exist.

3. Notwithstanding a) and b), the public policy exception should always be considered. Furthermore, Position of local creditors under the jurisdiction of China should not be undermined by the recognition.

4. Be cautious of that request for arrest a ship based on admiralty lien may be lifted by bankrupt protection.

There is no detailed provisions with respect to the conflicts between the bankruptcy proceeding and secured claims, especially claims made by arrest of the debtor's ship. Proceeding of ship's arrest and auction are provided in chapter 3 of Maritime Procedure Law of The People' Republic of China. Whereas article 19 of the Bankruptcy Law stipulated that all preservation measures taken against the debtor's property shall be lifted and enforcement procedures shall be stayed, once the court accepts the bankruptcy petition. Therefore, when the creditors request to a court in China for arrest a ship, they should be cautious of that their request be lifted by bankrupt protection.

\section{Conclusion and Prospect}

As the globalization of economy accelerates greatly, more and more cross-border trade and investment is inevitably coming in being, resulting in many bankruptcy cases in which the relationship of creditor's rights and debts is no longer limited to the territory of a country. The Model Law on
Cross-border Insolvency, adopted by United Nations Commission on International Trade Law, aims to solve the complex legal problems of cross-border insolvency. Presently, China hasn't enacted the Modal Law. Cross-boarder companies should be aware of the practices of cross-boarder insolvency under Chinese law and cross-boarder shipping companies should also be aware of the conflicts between admiralty lien and cross-boarder insolvency proceedings when dealing with the related issues, so that the interests the said companies can be protected to the maximum.

China is deeply furthering its open-up and reform, including the legislation system, to strengthen its international cooperation with other countries in the world. This can be reflected in "the Belt and Road Initiative". China is also in increasing demand of development of the wide cooperation of cross-border insolvency, hence, practices of Model Law and practices under other major economics' jurisdiction may be consulted to. Besides, China set the goal of establishment of maritime judicial center in March 2016, therefore it is predictable that the conflicts between bankruptcy law and maritime proceeding will be solved by referring to normal practice of modern shipping jurisdictions.

\section{References}

[1] PJ Omar. Cross-border jurisdiction and assistance in insolvency: The position in Malaysia and Singapore [J]. Potchefstroom Electronic Law Journal, 2008, 11 (1).

[2] Eugene Y C Wang, Jacky C K Yeung, Linsey Chen. Modified Universalism and the Proposed Adoption of the UNCITRAL Model Law on Cross-Border Insolvency in Hong Kong-From the Hanjin Shipping Bankruptcy Case [J]. Journal of Maritime Law and Commerce, 2019, 50 (1).

[3] Liu Yao. A study on the legal issues of International Cooperation in Cross-border bankruptcy in China--Taking Hanjin bankruptcy case as an example [J]. Chinese Journal of Maritime Law. 2018 (03). (In Chinese).

[4] B Wessels. Cross-Border Insolvency Law in Europe: Present Status and Future Prospects [J]. Potchefstroom Electronic Law Journal, 2008, 11 (1).

[5] Anca Roxana Adam. The creditor as participant in insolvency proceedings [J]. Challenges of the Knowledge Society, 2014, $4(-)$.

[6] Liu Bei. Study on the application of cross-border insolvency law [J]. Journal of Harbin University. 2018 (05). (In Chinese).

[7] Song Jianli. Judicial response to Cross-border bankruptcy cases [J]. People's judicature, 2018 (22): 30-33. (In Chinese).

[8] Li Zhu, Hu Zhengliang, A reconsideration on adopting the UNCITRAL Model Law on Cross-Border Insolvency in China triggered by the bankruptcy of Hanjin Shipping [J]. Chinese Journal of Maritime Law, 2019, 30 (02): 68-80.

[9] Dave De ruysscher. At the end, the creditors win: pre-insolvency proceedings in France, Belgium and the Netherlands (1807-c1910) [J]. Comparative Legal History, 2018, 6 (2). 
[10] Du Tao, Chen Li, Conflict of laws [M], Fudan University Press 2008.

[11] Hon Justice Steven Rares. Ship Arrests, Maritime Liens and Cross Border Insolvency [A]. 2017 issue of the sixth World Ocean Congress [C], 2017: 1.

[12] Daiga Sproge. The Debtor's Property Selling in the Cross-Border Insolvency Proceedings [J]. Economics and Culture, 2016, 13 (1).
[13] Luo Lan. Cross-border bankruptcy will have laws to follow in China [J]. Great economy and trade. 2007 (01).(In Chinese).

[14] Li Luling, Zhang Siyuan. The enlightenment of Hanjin bankruptcy case to the construction of recognition and relief system of Cross-border insolvency in China [J]. Chinese market. 2019 (15). (In Chinese).

[15] Michael Douglas. Characterisation of a foreign maritime lien by the lex fori $[\mathrm{J}]$. Oxford University Commonwealth Law Journal, 2017, 17 (1). 